\title{
O ACESSO À JUSTIÇA DOS HIPOSSUFICIENTES NA NOVA AÇÃO POSSESSÓRIA
}

\section{Carlos Fernando de Barros Autran Gonçalves*}

Resumo: Este artigo cuida do acesso à justiça dos hipossuficientes no procedimento especial das ações possessórias previstas na nova legislação processual civil. Objetiva-se examinar o direito de posse correlato ao acesso à justiça, bem como, as novas regras processuais civis e o sistema multiportas de solução dos conflitos coletivos de posse. Adota-se o método qualitativo com abordagem hipotético-dedutiva.

Palavras-chave: acesso à justiça; hipossuficientes; ações possessórias; posse; mediação.

\section{THE DUE PROCESS OF THE POOR RIGHTS IN NEW PROCEDURAL CIVIL LAW}

Abstract: This paper approaches the poor rights due process into special procedural civil law on new procedural civil law. The goals are study the due process about the ownership and the new alternative dispute resolution of the group property rights on new legal system. This paper apply qualitative and deductive-hypothetical method.

Palavras-chave: due process; poor rights; ownership; property; alternative dispute resolution.

\section{INTRODUÇÃO}

As ações possessórias dispostas no Novo Código de Processo Civil estão presentes entre os artigos 554 e 568. As inovações processuais da tutela possessória anterior atendem, sobretudo, ao acesso à justiça dos hipossuficientes. No viés agrário, estas novas regras processuais cumprem o programa constitucional traçado no parágrafo único do art. 126, da Constituição Federal, que preceitua a presença física do juiz no local do litígio, sempre que necessário, segundo o teor do art. 565, $\S 3^{\circ}$, do Novo Código de Processo Civil.

Junto com a busca pela efetividade da tutela possessória, os dispositivos que contemplam a coletividade de pessoas e a hipossuficiência econômica vêm ensejar uma integração hermenêutica ao direito de posse. A problemática proposta neste estudo está ligada à dinâmica substancial do direito de posse. Questiona-se: até que ponto a mudança legislativa das ações possessórias remodelou o devido processo de acesso à justiça? Nesta questão, está implícito que o acesso à justiça conduz à própria discussão sobre o direito de posse. A opção

\footnotetext{
* Graduado em Direito (UNIP/1997). Mestre em Teoria do Direito (UFPE/2010). Doutorando em Direito Processual (PUCRS). E-mail: autran.juris@gmail.com
}

Revista Cidadania e Acesso à Justiça | e-ISSN: 2526-026X | Porto Alegre | v. 4 | n. 2 | p. 20 - 38 | Jul/Dez. 2018 
metodológica é hipotético-dedutiva (MEZZAROBA e MONTEIRO, 2006), pois se formula o seguinte enunciado hipotético: o novo procedimento ajustou os conflitos possessórios ao acesso dos hipossuficientes à justiça. Sujeito à refutação ou à corroboração, a referida hipótese pode ser deduzida da própria legislação processual civil, ao passo que só a experiência judiciária brasileira poderá indicar a qualidade do acesso à justiça.

Objetiva-se imprimir esta ótica integrativa do sistema jurídico brasileiro, pertinente ao acesso à justiça no novo procedimento especial das ações possessórias. O presente artigo tem justificativa na análise sistemática do acesso à justiça, do acesso à posse e do acesso à propriedade. A metódica constitucional desta mudança já havia influído no Código Civil de 2002, por força do princípio da função social da propriedade, inscrito no rol dos direitos e garantias fundamentais (Constituição Federal, art. $5^{\circ}$, XXII), bem como, no conjunto dos princípios da ordem econômica e financeira (Constituição Federal, art. 170, III).

\section{Objeto das Ações Possessórias}

O objeto das ações possessórias é a posse exercida sobre o bem imóvel, que pode ser legalmente definida como sendo os poderes de fato inerentes à propriedade. Estas ações também recebem a terminologia de interditos possessórios, por causa deste traço característico. Interdita-se um estado fático de posse, e não o estatuto jurídico que a legitima. Deste modo, os direitos reais ou pessoais sobre a coisa, que não reclamam proteção da posse, não são objeto das ações possessórias.

Esta posse pode ser legitimada, como dito, por algum direito real. No usufruto e na servidão, por exemplo, o usufrutuário e o titular do prédio dominante exercem um poder de fato, respectivamente, que os qualifica como possuidor nestas situações. Esta qualidade de possuidor atinge aos titulares dos demais direitos reais sobre coisa alheia; ao superficiário no direito de superfície, ao promitente comprador da promessa irretratável de compra e venda do imóvel, bem como os credores fiduciários, pignoratícios, hipotecários e anticréticos. No entanto, a legitimação da posse não é o que define estes direitos reais; tais atributos de direito real são a causa de cada uma destas posses.

A causa possessionis nem sempre está lastreada por um direito que a fundamente. Pode o possuidor exercer uma posse autônoma, também tutelada por ação possessória, visto 


\section{O ACESSO À JUSTIÇA DOS HIPOSSUFICIENTES NA NOVA AÇÃO POSSESSÓRIA}

que remete à posse do bem imóvel. Desta maneira, a posse exercida sobre o bem imóvel pode estar concentrada apenas sobre o poder de fato, como pode estar vinculada a algum poder de direito, sendo a fonte deste último algum direito pessoal ou real. Mesmo em tais legitimações possessórias provindas de um direito pessoal ou real, a adequação da tutela específica à proteção da posse se restringe à posse como objeto. Por exemplo, sabe-se que o contrato de locação de imóvel urbano garante ao locatário o direito pessoal de exercer a posse sobre o bem, mas a pretensão da ação de despejo é o desfazimento do vínculo locatício, mais amplo do que a posse; logo não cabendo aqui a ação possessória.

A ação possessória também não prospera quanto aos vínculos obrigacionais que ensejam o domínio sobre a coisa, cujo preço pago pelo bem gera um "compromisso de entrega de coisa, e não a efetiva entrega da coisa. Vale dizer, a obrigação de dar gera um crédito, e não um direito real" (NERY, 2015, p. 169). A tutela processual adequada para exigir o cumprimento desta obrigação de entrega da coisa certa é disposta no art. 538, do Novo Código de Processo Civil, com previsão também na lei processual anterior.

Neste plano do domínio, é pertinente a ação de imissão de posse. Alguém que pretenda ser imitido na posse como possuidor de um bem imóvel, não está restituindo a posse, visto que só é possível restituir aquilo que já está instituído. Na imissão da posse, pretende-se integrar o legítimo dono à posse; e não reintegrar na posse do bem. A pretensão ao domínio antecede à posse no objeto da ação de imissão.

Eis as distinções entre juízo petitório e juízo possessório. O juízo petitório alcança tanto os direitos pessoais que versam sobre o domínio, quanto os direitos reais taxados no art. 1225, do Código Civil. O cônjuge que exerce direito pessoal sobre o bem imóvel penhorado em processo de execução no qual é executado o outro cônjuge faz jus aos embargos de terceiro, como prevê o art. 674, § 2º I, do Novo Código de Processo. O proprietário que exerce direito real sobre o bem imóvel pode reaver a coisa por meio da ação de reivindicação, conforme lhe autoriza o art. 1228, caput, do Código Civil.

No sistema romano, a vindicação da posse só afetava aos bens móveis. No entanto, a citada vindicatória da posse é uma ação petitória, pois seu fundamento não é o quieta non movere, "deixando de ser fato puro e que por isso não é protegida a título de conservação do estado fático" (ALBUQUERQUE, 2013, pp. 1007-1008). Quando os artigos 1.218 e 1.222, do Código Civil, expressam a "reivindicação da posse", a leitura feita sobre tais dispositivos deve

Revista Cidadania e Acesso à Justiça | e-ISSN: 2526-026X | Porto Alegre | v. 4 | n. 2 | p. 20 - 38 | Jul/Dez. 2018 
ser a da "reintegração". Reivindica-se o direito sobre a coisa e não o exercício de fato, que simplesmente se realiza. Neste contexto da perda da posse, a posse deve ser restituída, no lugar de ser vindicada. Porém, nem sempre a proteção possessória atenderá apenas à restituição da posse, podendo também cumprir com o propósito de manter a posse ou mesmo prevenir a situação que acarrete à tutela processual preventiva.

Portanto, três fatos jurídicos desencadeiam as tutelas processuais específicas à proteção possessória. Da combinação do art. 1.210, do Código Civil, com os artigos 560 e 567, do Novo Código de Processo Civil, extrai-se que: um, em face da turbação (=fato jurídico), opera-se o direito de ser mantido na posse (=pretensão), pela via da ação de manutenção de posse (=tutela processual); dois, em razão do esbulho (=fato jurídico), gera-se o direito de ser restituído na posse (=pretensão), pela via da ação de reintegração da posse (=tutela processual); e três, em vista da violência iminente (=fato jurídico), cabe assegurar a posse (=pretensão), por meio do interdito proibitório (=tutela processual).

Quanto aos fatos jurídicos referidos, em síntese, conceitua-se turbação como sendo um embaraço ou obstáculo à livre fruição da posse; o esbulho como uma privação ou perda da posse; e a violência iminente como uma ameaça real e efetiva à posse. No entanto, nem sempre o juízo possessório poderá definir se a situação concreta envolve uma turbação ou um esbulho, ou mesmo uma mera ameaça à posse. Esta dificuldade é sanada pela aplicação do princípio da fungibilidade, que inaugura o capítulo das ações possessórias no Novo Código de Processo Civil, reproduzindo uma regra anterior.

\section{Reflexos dos Princípios Possessórios no Acesso à Justiça}

O princípio da fungibilidade, ou da conversibilidade, está previsto no caput do art. 554, do Novo Código de Processo Civil. Converte-se a ação de manutenção em ação de reintegração, ou esta última é convertida naquela, com o fundamento de prestar a tutela jurisdicional mais adequada e efetiva à proteção possessória. Ocorre em casos concretos ambíguos quanto à propositura adequada da ação possessória, como se dá no esbulho parcial, por exemplo, de parte ínfima do bem imóvel. Critérios quantitativos e qualitativos, voltados à quantidade da área tomada e à localidade do esbulho parcial, incidirão na concreção do fato jurídico, de forma tal que um esbulho parcial possa até mesmo caracterizar uma turbação.

Revista Cidadania e Acesso à Justiça | e-ISSN: 2526-026X | Porto Alegre | v. 4 | n. 2 | p. 20 - 38 | Jul/Dez. 2018 


\section{O ACESSO À JUSTIÇA DOS HIPOSSUFICIENTES NA NOVA AÇÃO POSSESSÓRIA}

Convém que seja dado prazo hábil para que o autor da ação possessória que foi convertida reformule o pedido. Na conversão judicial da ação de interdito proibitório em outra ação possessória, inclusive, deverá o autor comprovar os requisitos expressos no art. 561, do Novo Código de Processo, segundo estabelece a parte final do art. 554, provendo "a proteção legal correspondente àquela cujos requisitos estejam provados". O art. 561, III, por exemplo, exige que seja provada a data da turbação ou do esbulho, sendo esta comprovação essencial, sobretudo, para regular o rito processual; se é caso de rito especial ou de rito comum, a depender da eficácia nova ou velha atribuída ao procedimento da ação possessória.

Ressalve-se que é inadmissível haver fungibilidade entre reivindicatória ou imissão de posse e ações de reintegração ou de manutenção de posse, tendo em mente que o objeto das ações possessórias é restrito à posse. Esta impossibilidade processual decorre da aludida diferença entre os juízos petitório e possessório. Mas não só por esta razão processual é juridicamente impossível confundir as ações relativas ao domínio com as ações possessórias, pois há também um princípio de direito material em jogo, inscrito no art. $1.210, \S 2^{\circ}$, do Código Civil de 2002.

O princípio da proibição da "exceção da propriedade", previsto no referido dispositivo do Código Civil, não impede a propositura da ação possessória quando for alegado qualquer direito sobre a coisa pela apresentação de título válido. Este princípio abrange tanto o proprietário como qualquer outro titular de direito real, desvinculando a mera titularidade ipso iuri do postulante, de um lado, do processamento e do desfecho da ação possessória, do outro. Esta legitimação de posse garante a proteção possessória independente das questões de domínio, encontrando um paralelo no art. 557, do Novo Código de Processo Civil.

Trata-se do princípio da proibição do reconhecimento do domínio, expresso no caput do referido art. 557, do Novo Código de Processo Civil. Este dispositivo altera, porém, a regra processual antes vigente, na medida em que excepciona a pretensão de terceira pessoa sobre o domínio. A Súmula 487, do Supremo Tribunal Federal, portanto, ao declarar que "será deferida a posse a quem, evidentemente, tiver o domínio, se com base neste for ela disputada", continua não sendo aplicada às ações possessórias, como leciona Luiz Guilherme Marinoni (2015), tendo utilidade reduzida às ações petitórias.

Nota-se que alguns dos princípios do direito de posse dispostos no Código Civil têm efeitos processuais, ou são de natureza processual. No entanto, nem todos os princípios das 
ações possessórias alcançam esta dimensão processual. Este é o caso da autotutela possessória, permitida no art. 1.210, $\S 1^{\circ}$, do Código Civil. Se considerarmos a acepção substantiva de ação, este princípio pré-processual somente será trazido no processo para justificar o ato próprio do possuidor que agiu mediante o exercício legítimo: (i) da defesa da posse, para mantê-la; (ii) ou do desforço imediato, para restituir a posse perdida. Eventual abuso de direito do possuidor pode gerar perdas e danos por ato ilícito, segundo o teor do art. 187 do Código Civil, em face da violação do fim econômico e social ou da boa-fé objetiva. Estes limites dos atos de posse estão, inclusive, regrados no mencionado art. $1.210, \S 1^{\circ}$, do Código Civil.

Deste modo, é preciso reconhecer três aspectos sistêmicos destes princípios que são interligados à mudança das ações possessórias no Novo Código de Processo Civil. O primeiro destes aspectos é dinâmico e consiste em que os atos não processuais do possuidor resultam em princípios substanciais das ações possessórias, sendo a posse um ato-fato jurídico no qual do "ato jurídico processual nasce a relação jurídica processual, com todas as suas consequências" (PONTES DE MIRANDA, 1972, p. 272). O segundo destes aspectos é estrutural e compõe os princípios estruturantes do direito de posse que são correlacionados ao procedimento especial das ações possessórias do Novo Código de Processo Civil, assim como ao Código Civil de 2002 e à Constituição Federal de 1988. O terceiro e último dos aspectos é funcional e orienta a interpretação e aplicação do direito de posse e das ações possessórias.

Da análise metodológica destes três aspectos sistêmicos, fundamenta-se a leitura das mudanças no procedimento especial das ações possessórias. A começar pelo primeiro, vemos que a base normativa que sustentou o projeto de mudança do Código Civil de 2002 influiu sobre o novo Código de Processo Civil. Neste sentido, o espírito do denominado "novo antropocentrismo" (DELGADO, 2011, p. 297) corporificou a tutela coletiva da posse, pois o possuidor individual foi inserido em um contexto social da ação possessória, fazendo com que o princípio da socialidade do Código Civil tenha inspirado também o Novo Código de Processo Civil. Além desta mudança, o Novo Código de Processo Civil também passou a promover a instrução in loco do juízo possessório para realizar o direito de posse, o que equivale ao princípio da operabilidade no direito civil.

Quanto ao segundo e terceiro aspectos, a análise estrutural-funcionalista das ações possessórias nos leva ao princípio da função social da posse. Ainda que não esteja expresso, 


\section{O ACESSO À JUSTIÇA DOS HIPOSSUFICIENTES NA NOVA AÇÃO POSSESSÓRIA}

este princípio tem fundamentos doutrinários de peso e está implícito à diretriz constitucional da função social da propriedade. Em relação à propriedade, o princípio da função social "aplica-se, com mais razão, à posse, pois é esta que a realiza, na dimensão positiva da utilização real da coisa" (LÔBO, 2015, p. 115). Luiz Edson Fachin registrou que a "constitucionalização do direito à terra se traduz mais na função social da posse" (FACHIN, 2015, pp. 97-98). Esta interpretação pode gerar efeitos processuais de não seguimento da ação possessória, diante dos limites objetivos que o princípio da função social imprime no campo dominial. Se for questão de domínio, não caberá seguir à ação possessória; ela não prospera por haver tutela processual específica ao reconhecimento do domínio, seja na usucapião, seja em outra ação adequada ao juízo petitório, como é do feitio das ações positivas ou negativas para reconhecer ou negar os direitos reais limitados.

O princípio da duplicidade, ou dos efeitos dúplices das ações possessórias, é diferente nestes termos de seguimento do processo, pois ele garante ao réu os mesmos direitos que o autor pode reclamar. Em razão da cumulação típica dos pedidos que o autor poderá formular junto com o pedido de manutenção ou de restituição da posse, o réu não precisa reconvir no processo para requerer na contestação os mesmos pedidos. Pelo teor tipificado no art. 555, do Novo Código de Processo Civil, autor e réu poderão cumular a ação possessória com: (i) condenação em perdas e danos; (ii) indenização dos frutos; (iii) medida judicial para evitar nova turbação ou esbulho; e (iv) cumprimento da tutela provisória ou final.

Nas ações possessórias há uma lógica decisória inerente ao pressuposto de duplicidade. Se for procedente a restituição de posse do autor, necessariamente não há procedência da manutenção de posse do réu, nas ações de esbulho; se for procedente a manutenção nas ações de turbação, há improcedência do pedido de restituição do réu. A via de mão-dupla implicada na ação e na contestação invalida um dos pedidos para dar lugar ao outro. A exclusão de uma terceira possibilidade de escolha na decisão judicial faz operar a lógica do terceiro excluído, "expresso da seguinte maneira: 'p v p', desde que se considere esse 'v' como uma conjunção excludente" (CASTRO Jr., 2009, p. 184). Este espelho lógico duplo das ações possessórias está previsto no art. 556, do Novo Código de Processo Civil.

Para finalizar, ainda há dois princípios das ações possessórias que estão no Código Civil, mas têm efeitos processuais. Um deles é o princípio da boa-fé subjetiva, que resultará em relevante qualificação para apreciar o direito aos frutos, a indenização por benfeitorias e o

Revista Cidadania e Acesso à Justiça | e-ISSN: 2526-026X | Porto Alegre | v. 4 | n. 2 | p. 20 - 38 | Jul/Dez. 2018 
direito de retenção do possuidor que devolverá o bem ao restituído na posse. A boa-fé subjetiva é uma exceção no ordenamento jurídico em geral, além de nem sempre evidenciar de forma expressa as situações referentes a este tipo de boa-fé, como se dá na hipótese de quitação do devedor que paga ao credor putativo, pensando ser este o credor real. Em matéria de posse, entretanto, a legislação civil preferiu dispor sobre o significado de boa-fé subjetiva, para admiti-la como regra neste tópico.

A opinião firmada neste estudo é a de que a ação possessória interromperá a boa-fé subjetiva quando houver ciência da mesma pelo réu, visto que a ação possessória é tida no direito material e processual, consoante a dicção legal do art. 1.202 do Código Civil; ou seja, uma interpelação extrajudicial que cientifique o possuidor tem o efeito de perda da boa-fé. Todavia, esta eficácia dependerá de decisão judicial que determine a restituição da posse para retroagir nos seus efeitos constitutivos da má-fé do possuidor, desde o momento em que este teve ciência de que deveria restituir o bem. Para Orlando Gomes, a "maioria adota o critério segundo o qual a boa-fé cessa, para os efeitos legais, com a contestação da lide" (GOMES, 2004, p. 57). O momento da citação judicial é mais processual do que ligado ao direito material. Perdida a boa-fé, devido à acepção subjetiva, são aplicáveis os efeitos da posse de má-fé.

Os vícios objetivos são distintos da má-fé, pois esta última é vício subjetivo. O sujeito só transmite o vício objetivo, salvo se der conhecimento do fato ao possuidor posterior. Os atos violentos, clandestinos e precários, caracterizadores do vício objetivo do possuidor, estão elencados de modo não taxativo no art. 1.200 do Código Civil. O princípio da continuidade do caráter de posse, expresso no art. 1.203 do Código Civil, faz perpetuar estes vícios objetivos. Se uma posse for adquirida de forma injusta, o vício objetivo acompanhará a posse do possuidor posterior na transmissão da posse de um para outro. $\mathrm{O}$ possuidor posterior poderá alegar sua boa-fé, mas não poderá refutar o vício objetivo que macula o direito de posse, exceto na hipótese de anulação do vício. A aludida hipótese legal, embora também presente na lei civil, tem solução doutrinária na legislação processual. Esta é uma das razões de ser do Novo Código de Processo Civil manter a posse nova e a posse velha no sistema processual da ação possessória.

\section{Eficácia Possessória no Acesso à Justiça}




\section{O ACESSO À JUSTIÇA DOS HIPOSSUFICIENTES NA NOVA AÇÃO POSSESSÓRIA}

A reprisada senectude da posse já vigia na lei processual anterior, estando igual e temporalmente definida no art. 558 do novo Código de Processo Civil, para tratar das situações em que a ação possessória não foi intentada dentro de ano e dia da data do conhecimento do fato que provocou a respectiva ação. O efeito processual da ação possessória de força velha é de natureza procedimental, mantendo esta ação o seu caráter de posse, mesmo que em curso no procedimento ordinário. Nada impede que o juízo possessório conceda a antecipação dos efeitos da tutela na ação de força velha; porém, quando comparada à ação de força nova, os requisitos comprobatórios exigidos na antecipatória dos efeitos da tutela de posse velha ensejam maiores óbices do que a medida liminar do procedimento especial.

Anteriormente, a única distinção processual fazia enquadrar a posse nova ao procedimento especial e a posse velha ao procedimento ordinário. Hoje ainda existe esta distinção no referido art. 558 do Novo Código de Processo. Todavia, o art. 565, caput, do Novo Código de Processo Civil, trouxe a novidade da audiência de mediação quando se tratar de litígio coletivo possessório, estabelecendo tal determinação apenas às ações de posse velha. O juízo possessório deverá, neste contexto, designar a audiência de mediação em até trinta dias, com a participação do Ministério Público e, se necessário, da Defensoria Pública, além dos órgãos responsáveis pela política agrária ou urbana.

Em referência ao procedimento especial da ação de posse nova, o art. 562 do Novo Código de Processo Civil preceitua sobre a liminar inaudita altera pars (sem antes ouvir a parte contrária) ou, em não sendo concedida a liminar, sobre a audiência de justificação designada com a citação do réu. A medida liminar contrária ao réu tem fundamento na "tutela de evidência", que não é admitida nas ações possessórias quando a parte ré for pessoa jurídica de direito público, representada pela Fazenda Pública, como já ditava a lei processual anterior, ora presente no parágrafo único do art. 562 do Novo Código de Processo Civil.

A dinâmica temporal da ação possessória de força velha pode afetar a causa da posse. Esta causa da posse é permanente, em tese, por força do princípio do contínuo caráter de posse disposto no Código Civil. Todavia, a temporalidade que gera prescrição também pode incidir em aquisição de direito, como acontece na posse apta à usucapião pelo decurso do tempo definido em lei. A questão de direito consiste em perquirir se a incidência temporal da

Revista Cidadania e Acesso à Justiça | e-ISSN: 2526-026X | Porto Alegre | v. 4 | n. 2 | p. 20 - 38 | Jul/Dez. 2018 
posse velha é capaz de excepcionar a aplicação do princípio da continuidade do caráter de posse pelo critério objetivo do tempo de um ano e dia.

Há um debate doutrinário neste sentido. O cerne do debate é tempo que a posse velha sugere para fins de legitimar os atos possessórios oriundos de uma posse violenta ou clandestina. $\mathrm{Na}$ exegese do art. 1.208 do Código Civil, exclui-se a posse precária das hipóteses de convalidação da posse legítima, mas se permite que os atos violentos ou clandestinos sejam cessados. Do ponto de vista técnico jurídico, portanto, a precariedade da posse, que diz respeito ao término da relação jurídica que legitimava a posse, resulta na mais grave espécie de posse injusta, pois a lei civil não reconhece a possibilidade de convalidar tal vício.

Violência é coação física ou moral; e clandestinidade é ocultação sem que o possuidor legítimo pudesse conhecer o vício, objetivamente, como se dá "na calada da noite". Para Farias e Rosenvald, "enquanto não cessam os atos de violência por parte do esbulhador, há mera detenção (art. 1.208 do CC) e, portanto, o início da contagem do prazo decadencial coincide com o dia em que termina o uso da força e da ameaça" (FARIAS e ROSENVALD, 2015, p. 185). O prazo decadencial referido pelos autores é o de um ano e dia, que está previsto no citado dispositivo do novo Código de Processo Civil.

A doutrina qualifica de detentor todo aquele que não exerce o poder de fato sobre o bem. No Código Civil, a detenção está definida no art. 1.198. Entretanto, nesta disposição legal, o detentor é aquele que tem um vínculo de subordinação para com o possuidor ou o proprietário. Está claro que isto não inclui aquele que exerce uma posse injusta. Podemos indagar, então, por qual motivo uma parte da doutrina considera como detentor aquele que é possuidor injusto, se este não tem qualquer nexo que o aprisione ao possuidor ou o proprietário.

A explicação jurídica é técnica e, também, legal. Tecnicamente, o possuidor é aquele que tem o direito de posse e a garantia da tutela possessória. Poderá o possuidor, direto e indireto, ser legitimado no exercício da posse e promover ação possessória. Por outro lado, o detentor não tem o direito de posse, nem tampouco a proteção possessória. Falta legitimação para o detentor compor a lide possessória, não podendo figurar como sujeito da relação jurídica processual, devendo indicar quem é o autor legitimado para atuar no processo. Daí procede o instituto processual da nomeação à autoria, disposto no revogado art. 62 da antiga

Revista Cidadania e Acesso à Justiça | e-ISSN: 2526-026X | Porto Alegre | v. 4 | n. 2 | p. 20 - 38 | Jul/Dez. 2018 


\section{O ACESSO À JUSTIÇA DOS HIPOSSUFICIENTES NA NOVA AÇÃO POSSESSÓRIA}

lei processual civil, cujo teor pode ser localizado no art. 338 do Novo Código de Processo Civil, a respeito da ilegitimidade da parte.

O possuidor injusto, no entanto, não indicará a sua ilegitimidade. Terá esta que ser arguida pela parte adversa, em contraditório instaurado nesta questão preliminar. Por isto, esta detenção é categorizada como autônoma ou independente, por não guardar um vínculo de subordinação entre o detentor e o possuidor ou proprietário. A explicação de ordem legal que justifica o enquadramento dogmático do possuidor injusto em uma modalidade de detenção é fiel à letra da lei, que não nomina a posse injusta, mas declara que "é justa a posse que não for violenta, clandestina ou precária", nos exatos termos do art. 1.200 do Código Civil. Ou seja, o legislador civil evitou empregar a expressão posse injusta para tratar do que não é posse justa. Assim, o termo posse injusta se revela como sendo uma criação doutrinária sem amparo legal, que pode ser interpretada de modo não técnico para simplificar a definição do que "não é posse justa".

A posição contrária à categoria da detenção autônoma ou independente na doutrina tem aceitado a validade da posse injusta para efeitos de proteção possessória. A posse injusta, neste caso, é uma espécie de posse e não de detenção. A literalidade da lei civil não é levada em conta neste entendimento. Nas palavras de Flávio Tartuce, tratar a posse injusta como detenção "causa perplexidade, pois nega o conceito de posse injusta, entrando em clara contradição com o art. 1.200 da própria codificação" (TARTUCE, 2015, p. 289). Prossegue o autor nesta "linha que reconhece na posse injusta a existência de posse, e não de detenção" (TARTUCE, 2015, p. 289). Contudo, o autor não aprofunda o traço hermenêutico que, como defende, caracteriza a posse do possuidor injusto, contrariando ainda o preceito do art. 1.208 do Código Civil, que só permite a existência da posse após a cessação dos atos violentos ou clandestinos.

Neste contexto, todavia, é mais uma vez relevante distinguir o sentido de pretensão no direito material, de um lado, da legitimidade processual para propor a ação possessória, do outro. Na perspectiva do processo civil, só é possível reconhecer a posse injusta no processo e pelo processo, o que potencializa e legitima a propositura da ação possessória pelo possuidor injusto. No entanto, verificada no processo que não é justa a posse, os efeitos legais concernem à detenção do injusto, devido à desqualificação deste possuidor na ordem jurídica. 
Logo, procede-se à ação possessória, mas não procedem os efeitos da posse, uma vez constatada a "não-posse" do mero fâmulo de posse.

\subsection{Da Restituição com Retenção}

Dentre os efeitos da posse, apenas ao possuidor de boa-fé é assegurado, nos termos do art. 1.219 do Código Civil, o direito de reter o bem pelo valor das benfeitorias necessárias e úteis realizadas. Para que se dê este efeito, porém, é exigido o dispêndio de recursos ou de trabalho daquele que deve restituir o bem, de acordo com a regra geral das obrigações de restituição da coisa certa, nos termos do art. 242 do Código Civil. A indivisibilidade do bem imóvel impede que o direito de retenção seja operado em parte da posse, por conta da impossibilidade física e jurídica da devolução parcial.

O direito de retenção deve ser alegado na contestação ou na reconvenção do processo. Desnecessária é a reconvenção, devido ao caráter dúplice da ação possessória, que foi explanado em matéria de princípios. Para Carlos Roberto Gonçalves, predomina "o entendimento de que não cabem embargos do executado em ação possessória, porque a sentença tem força executiva" (GONÇALVES, 2013, p. 167). É certo que os embargos de retenção por benfeitorias são admitidos, por comporem o conflito possessório.

A força executiva do mandado de reintegração de posse não permite o ingresso dos embargos. Se for posse nova, não há sequer espaço para os embargos. A posse velha tampouco altera a natureza executória da decisão no juízo possessório. Se faltou o pedido de retenção na contestação, houve a preclusão do direito de reter o bem; no entanto, não gerou preclusão do direito de ser indenizado pelas benfeitorias. Deverão estas ser objeto de posterior ação civil indenizatória.

\subsection{Da Reparação Civil Oportuna}

A posse pode ser restituída com a continuidade do pedido cumulado à ação possessória. Devolvida a posse do bem, então, autor e réu poderão seguir no feito para receber as indenizações que lhes são devidas. A reciprocidade de pagamentos a título de ressarcimento mútuo pode gerar a compensação dos danos causados um ao outro, como 


\section{O ACESSO À JUSTIÇA DOS HIPOSSUFICIENTES NA NOVA AÇÃO POSSESSÓRIA}

faculta o art. 1.221 do Código Civil. A existência da dívida no tempo certo é o requisito para compensar o pagamento gerado pelas benfeitorias; ou seja, tais benfeitorias devem existir ao tempo da evicção. Se feitas posteriormente, só cabem quanto às benfeitorias necessárias para prevenir responsabilidade civil do possuidor que der causa ao prejuízo.

O possuidor de má-fé tem direito de ser ressarcido pelas despesas de custeio dos frutos devolvidos e, também, pelas benfeitorias necessárias. O fundamento é evitar o enriquecimento sem causa do possuidor reintegrado na posse do bem. Contudo, quanto às benfeitorias necessárias, como informa Lôbo sobre o posicionamento de Pontes de Miranda, o ressarcimento "não decorre do enriquecimento sem causa, pois a benfeitoria necessária pode existir e não constituir enriquecimento" (LÔBO, 2015, p. 75). Se é necessária a benfeitoria, serviu ao possuidor que a realizou e, mais do que uma obrigação civil, foi um dever de conduta possessória. $\mathrm{O}$ art. 1.220 do Código Civil impõe, todavia, tal ressarcimento para o possuidor de má-fé.

O problema processual atinente aos direitos do autor e do réu corresponde à preclusão consumativa, na hipótese de não ser feito o pedido indenizatório na primeira oportunidade de manifestação no processo. Deve o autor formular o pedido na petição inicial, cumulando a ação possessória com o pedido indenizatório. Cabe ao réu expor os fundamentos jurídicos que baseiam o pedido indenizatório no momento da contestação, junto com o pedido de restituição ou de manutenção da posse. Porém, caso não ocorram tais manifestações oportunas do autor e do réu na ação possessória, em ação própria posterior caberá comprovar o enriquecimento sem causa e justificar a falta do pedido em momento oportuno.

Não obstante o interesse privado pela celeridade processual seja daquele em favor do qual se aplica o ressarcimento, a justificação da falta do pedido que poderia ser cumulado na ação possessória respeita ao princípio do contraditório. É a defesa do autor ou do réu que está em questão quando há um novo processo acerca do que, em tese, já deveria ter sido desenvolto na discussão processual da posse. Conforme apontam José Tesheiner e Rennan Thamay, o princípio do contraditório "concentra-se na expressão audiatur et altera pars (ouça-se também a outra parte), o que importa em dar-se ao processo uma estrutura dialética" (TESHEINER e THAMAY, 2015, p. 74). A abertura para oportunizar a ação indenizatória, assim, também deverá promover a oportunidade ampla da contradita. 


\section{Acesso Individual e Acesso Coletivo à Justiça}

A inovação processual das ações possessórias permite classificá-las quanto à classe dos conflitos possessórios de duas formas: (i) pelo conflito individual; ou (ii) pelo conflito coletivo. O conflito individual estava previsto na lei processual anterior. Assim, a novidade avança sobre os conflitos coletivos de posse. Nesta classe de conflitos, ainda existem duas hipóteses refletidas na lei processual. A primeira delas envolve um grande número de pessoas no polo passivo da demanda, como se refere o art. 554, $\S 1^{\circ}$, do Novo Código de Processo Civil. A segunda hipótese radica em um litígio coletivo, conforme expressa o art. 565, caput, do Novo Código de Processo Civil. Nesta segunda subcategoria de conflito coletivo, os possuidores poderão estar situados, inclusive, no polo ativo da demanda possessória.

$\mathrm{Na}$ análise de Erik Navarro Wolkart, a primeira subclasse de litígio coletivo pode ser chamada de "ação possessória multitudinária" (WOLKART, 2015, p. 895), exemplificada nas invasões dos movimentos dos sem-terra; e a segunda subclasse destes litígios permite o ingresso de ação civil pública, tal qual "a FUNAI ajuíza ação civil pública buscando reintegração de posse de determinada aldeia indígena invadida por garimpeiros" (WOLKART, 2015, p. 902). Em ambas as causas, estrutura-se uma composse, que está definida no art. 1.199 do Código Civil. Na composse, os compossuidores comungam dos mesmos direitos, não podendo excluir mutuamente tais direitos de posse. Dois problemas processuais podem advir daí: um que afeta à citação pessoal; e outro que indica à representação processual do grupo. Juntos, estes problemas tocam na questão referente a quem atuará no processo.

Nas ações de reintegração de posse contra compossuidores não identificados pelo autor do processo, o juízo possessório vinha preferindo tratar esta questão com a citação edilícia, ou com outra solução judicial. Afinal, em regramento anterior, coube ao juízo possessório "disciplinar a forma de citação, levando a efeito medida eficaz de divulgação da demanda" (WEDY e WELSCH, 2015, p. 159). O Novo Código de Processo Civil resolveu esta lacuna jurídica, nos parágrafos do art. 554. São normas procedimentais dirigidas ao oficial de justiça e à atividade jurisdicional. Conforme o teor do parágrafo primeiro, nos litígios coletivos tal atividade do juízo possessório deverá se fazer acompanhar do Ministério Público e, quando necessário, da Defensoria Pública.

Revista Cidadania e Acesso à Justiça | e-ISSN: 2526-026X | Porto Alegre | v. 4 | n. 2 | p. 20 - 38 | Jul/Dez. 2018 


\section{O ACESSO À JUSTIÇA DOS HIPOSSUFICIENTES NA NOVA AÇÃO POSSESSÓRIA}

$\mathrm{O}$ art. 554, $\S 1^{\circ}$, do Novo Código de Processo Civil, exige a citação pessoal dos ocupantes que estiverem no local e a citação edilícia dos demais. Quanto a estes, o parágrafo terceiro do mesmo dispositivo impõe que o juízo possessório dê ampla publicidade ao processo. No entanto, ainda que haja a citação pessoal de todos os supostos ocupantes, sem que se conheçam outros, em torno dos litígios coletivos de grandes proporções é recomendável que excepcionalmente o juízo possessório adote tal publicização, por medida de cautela, mesmo que a regra processual seja atinente apenas aos ocupantes que não foram vistos no local e, por isto, tenham sido citados por edital.

\subsection{Hipossuficiência e Mediação}

A função constitucional da Defensoria Pública dispensa regras impositivas quanto à participação da entidade nos processos que a vinculam. Contudo, a nova regra do art. 554, $\S$ $1^{\circ}$, prevê a intimação da Defensoria Pública em caso de hipossuficiência econômica dos réus envolvidos no conflito coletivo de posse. Também deve ser intimada a Defensoria Pública quando o polo ativo da ação possessória goza do benefício da gratuidade da justiça, como consta no art. 565, § $2^{\circ}$, do Novo Código de Processo Civil.

Para este último caso em que a gratuidade judiciária estiver no polo ativo da demanda possessória, cabe observar que a regra, nada inovadora, do art. 559 do Novo Código de Processo Civil, agora não é aplicada, pois a tutela assecuratória prevista na referida regra visa caucionar o réu quando a posse é provisoriamente deferida em favor do autor. Tal preceito processual firma que, se o réu provar a inidoneidade financeira do autor, poderá exigir caução para assegurar possível perdas e danos; porém, em situação de benefício gratuito da justiça, a inidoneidade do autor é evidente, o que do ponto de vista lógico invalida a posse provisória se a mesma só for concedida mediante caução. Nesta situação, argumentase logicamente que "descabe o pedido de caução, sob pena de inviabilizar-se a tutela provisória da posse, por via indireta" (MARINONI, 2015, p. 607).

Importa não confundir hipossuficiência econômica com vulnerabilidade. No direito privado em especial, existe uma "correlação entre a vulnerabilidade jurídica e o princípio do equilíbrio material, o que permite intervir na autonomia privada" (GONÇALVES, 2015, p. 108). No tocante às ações possessórias, se os hipossuficientes no sentido meramente 
econômico forem considerados vulneráveis, o processo de mediação previsto nos parágrafos do art. 565 do novo Código de Processo Civil sempre deslocará a tutela do Ministério Público para a guarda dos hipossuficientes. No entanto, nem sempre a hipossuficiência material está associada ao conteúdo jurídico da vulnerabilidade. Portanto, a função ministerial no processo de mediação das ações possessórias multitudinárias tem por escopo tutelar o direito, o que inclui os interesses indisponíveis que não podem ser objeto de mediação. Para que se dê a representação adequada dos hipossuficientes, a Defensoria Pública será intimada e acompanhará o feito possessório junto ao grupo de compossuidores.

$\mathrm{O}$ art. 565 do Novo Código de Processo Civil normatiza dois suportes fáticos distintos para que sejam designadas as audiências de mediação. Um deles é referente à posse velha no litígio coletivo inaugurado após um ano e dia da data do fato alegado na petição inicial. Nesta situação, como já foi mencionado no item 04 deste estudo, o juízo possessório deverá designar audiência de mediação para que esta seja realizada em até trinta dias. $\mathrm{Na}$ outra circunstância, conforme o art. 565, $\S 1^{\circ}$, a audiência de mediação deverá ser designada quando a medida liminar concedida pelo juízo possessório não foi executada no prazo de um ano, a contar da data de distribuição do mandado judicial ao oficial de justiça.

Nas ações de posse velha, entretanto, uma vez tramitadas no procedimento comum, a qualquer momento poderão as partes pleitear a audiência de mediação. Nada impede que também no procedimento especial seja manifesto o interesse da mediação. Sobretudo, na petição inicial o autor pode optar pela audiência de mediação do conflito, independente do litígio ser individual ou coletivo, segundo determina o art. 319, VII, do Novo Código de Processo Civil. Nestes casos, a mediação tem fundamento no propósito de não-litigância que norteou o Novo Código de Processo Civil, a partir do livre acesso à justiça, garantido no art. $5^{\circ}$, inciso XXXV, da Constituição Federal.

O direito de acesso à justiça gerou o "modelo multiportas" (THEODORO Jr., 2015, pp. 242-256), voltado à solução dos conflitos, no espírito da norma fundamental de processo disposta no art. $3^{\circ}, \S 3^{\circ}$, do Novo Código de Processo Civil. A mediação do conflito possessório está coerente com o aludido modelo de acesso à justiça.

\subsection{Da Composse ao Condomínio}




\section{O ACESSO À JUSTIÇA DOS HIPOSSUFICIENTES NA NOVA AÇÃO POSSESSÓRIA}

$\mathrm{O}$ art. 565, $\S 4^{\circ}$, do Novo Código de Processo Civil, apresenta uma novidade que articula o procedimento dos litígios coletivos de posse às políticas públicas de funcionalização da posse. A intimação dos órgãos responsáveis pela política agrária ou urbana, pertinente aos quatro entes da federação, demonstra a aproximação da nova lei processual com a realidade dos conflitos coletivos possessórios no país. Tais órgãos responsáveis podem ser intimados para participarem da audiência de mediação nesta classe de conflitos, cabendo-lhes expressar o interesse e a possibilidade ou não de solução do litígio coletivo.

Basicamente, podemos sistematizar quatro possibilidades de solução nesta classe de conflitos: (i) ou o litígio coletivo pode ser resolvido no juízo possessório, sem o avanço para a questão do domínio no juízo petitório; (ii) ou o litígio coletivo supera os limites da posse, por meio da desapropriação judicial indireta, prevista no art. 1.228 , $\S 4^{\circ}$ e $5^{\circ}$, do Código Civil; (iii) ou resvala no domínio pela declaração judicial da posse ad usucapionem, que não significa usucapião, mas sim posse apta para exercer a ação de usucapião especial urbana coletiva, regulada no Estatuto da Cidade (art. 10, da Lei $n^{\circ} 10.257 / 2001$ ); (iv) ou ultrapassa o objeto da posse para prover à desapropriação em processo autônomo fundado no interesse social, conforme o art. 1.228, $\S 3^{\circ}$, do Código Civil. Das quatro hipóteses, três delas saem da esfera da composse para incidir sobre o domínio, que não tem sede no juízo possessório. Assim, não compõem o tema deste estudo, exceto no que se refere ao parágrafo $5^{\circ}$, do aludido art. 565, do Novo Código de Processo Civil, que estabelece a aplicação do dito preceito nos litígios sobre propriedade do imóvel.

\section{CONCLUSÃO}

As ações possessórias inovaram, como foi explanado neste estudo, em razão da realidade jurídica dos conflitos coletivos de posse. Questões pragmáticas relativas à citação dos possuidores e à atuação dos órgãos responsáveis pelo litígio coletivo foram trazidas no novo sistema processual possessório. A garantia da Defensoria Pública está regulada nesta nova sistemática, como forma de acesso à justiça da coletividade que tem o benefício da gratuidade.

A mediação dos conflitos coletivos é outra novidade no sistema em geral, que favorece o mútuo entendimento como forma de composição do litígio possessório. Por 
integrar o modelo multiportas, a mediação dos conflitos de posse pavimenta o acesso à justiça da coletividade que está envolvida nos conflitos. Vimos que, devido também à referida audiência de mediação, há fundamento para manter a classificação da posse quanto à eficácia processual, em termos de força nova e velha.

O acesso à justiça dos hipossuficientes e da coletividade que têm pretensões jurídicas de posse foram contemplados neste artigo, que também buscou aprofundar o tema do direito de posse, para fins de substancializar a matéria do acesso à justiça. Assim, cumpriu-se com os objetivos específicos de correlacionar a estudada mudança do procedimento possessório com o direito de acesso à justiça.

\section{REFERÊNCIAS}

ALBUQUERQUE Jr., Roberto Paulino. Sobre a Ação Vindicatória no Direito Brasileiro / In. Pontes de Miranda e o Direito Processual. (org.) Fredie Didier Jr., Pedro Henrique Pedrosa Nogueira, e Roberto P. Campos Gouveia Filho. Salvador: Ed. Jus Podium, 2013.

CASTRO Jr., Torquato da Silva. A Pragmática das Nulidades e a Teoria do Ato Jurídico Inexistente: reflexões sobre metáforas e paradoxos da dogmática privatista. São Paulo: Editora Noeses, 2009.

DELGADO, Mário Luiz. Codificação, Descodificação e Recodificação do Direito Civil Brasileiro. São Paulo: Saraiva, 2011.

FACHIN, Luiz Edson. Direito Civil: sentidos, transformações e fim. Rio de Janeiro: Renovar, 2015.

FARIAS, Cristiano Chaves de; ROSENVALD, Nelson. Curso de Direito Civil - Reais, Volume 05. $11^{\mathrm{a}}$ ed. São Paulo: Editora Atlas S/A, 2015.

GOMES, Orlando. Direitos Reais; rev., atual. e aumentada por Luiz Edson Fachin. 19a ed. Rio de Janeiro: Editora Forense, 2004.

GONÇALVES, Carlos Fernando de Barros Autran. Acesso à Propriedade na Pragmática Civilista: releitura jurídica da tradição liberal privada pelas lentes multifocais dos Direitos Humanos / In. Direitos Humanos, Cidadania e Acesso à Justiça. (org.) Elcio de Gusmão Verçosa; Lana Lisiêr de Lima Palmeira; Pedro Henrique Nogueira. Maceió: Viva Editora, 2015.

GONÇALVES, Carlos Roberto. Direito Civil Brasileiro, volume 05: direito das coisas. $8^{\text {a }}$ ed. São Paulo: Saraiva, 2013.

LÔBO, Paulo. Direito Civil: Coisas. São Paulo: Ed. Saraiva, 2015.

MARINONI, Luiz Guilherme. Novo Código de Processo Civil Comentado / Luiz Guilherme Marinoni, Sérgio Cruz Arenhart, Daniel Mitidiero. São Paulo: Ed. Revista dos Tribunais, 2015. 
MELLO, Marcos Bernardes de. Teoria do Fato Jurídico: plano da existência. $18^{\mathrm{a}}$ ed. São Paulo: Saraiva, 2012.

MEZZAROBA, Orides; e MONTEIRO, Cláudia Servilha. Manual de Metodologia da Pesquisa no Direito. $3^{\mathrm{a}}$ ed. São Paulo: Saraiva, 2006.

NERY, Rosa Maria de Andrade. Instituições de Direito Civil: direito das obrigações, volume II / Rosa Maria de Andrade Nery, Nelson Nery Junior. São Paulo: Ed. Revista dos Tribunais, 2015.

PONTES DE MIRANDA. Tratado das Ações - Tomo I: Ação, classificação e eficácia. $2^{\mathrm{a}}$ ed. São Paulo: Ed. Revista dos Tribunais, 1972.

TARTUCE, Flávio. O Novo CPC e o Direito Civil. Rio de Janeiro: Forense; São Paulo: Método, 2015.

TESHEINER, José Maria Rosa; THAMAY, Rennan Faria Krüger. Teoria Geral do Processo: em conformidade com o Novo CPC. Rio de Janeiro: Forense, 2015.

THEODORO Jr., Humberto. Novo CPC - Fundamentos e Sistematização / Humberto Theodoro Jr.; Dierle Nunes; Alexandre Melo Franco Bahia; Flávio Quinaud Pedron - $2^{\mathrm{a}}$ ed. rev., atual. e ampl. - Rio de Janeiro: Forense, 2015.

WEDY, Gabriel; WELSCH, Gisele Mazzoni. A Ação Coletiva Passiva e os seus Pontos Controvertidos / In. Processos Coletivos: ação civil pública e ações coletivas. (org.) Antônio Gidi, José Maria Tesheiner, Tereza Cristina Sorice Baracho Thibau. Porto Alegre: Livraria do Advogado Editora, 2015.

WOLKART, Erik Navarro. Comentários ao Novo Código de Processo Civil / (coord.) Antonio do Passo Cabral; Ronaldo Cramer. Rio de Janeiro: Forense, 2015. 